\author{
Mehmet Akif Ersoy Üniversitesi Fen Bilimleri Enstitüsü Dergisi 12(2): 263-277 (2021) \\ The Journal of Graduate School of Natural and Applied Sciences of Mehmet Akif Ersoy University 12(2): 263-277 (2021)
}

Araştırma Makalesi / Research Paper

\title{
Kurakçıl Peyzaj Çalışmalarında Bitkisel Uygulamalar: Muğla-Sarıgerme Halk Plajı Örneği
}

\author{
Serap ÇÖP ${ }^{\text {D } 1}{ }^{1}$, Hülya AKAT ${ }^{\text {iD } 2^{*}}$ \\ ${ }^{1}$ Muğla Sıtkı Koçman Üniversitesi, Çevre Bilimleri Anabilim Dalı, Muğla \\ ${ }^{2}$ Muğla Sıtkı Koçman Üniversitesi, Ortaca Meslek Yüksekokulu, Muğla \\ Geliş Tarihi (Received): 07.05.2021, Kabul Tarihi (Accepted): 27.06.2021 \\ $\square$ Sorumlu Yazar (Corresponding author $\left.{ }^{\star}\right)$ : hulya_akat@hotmail.com \\ (C) +902522115879 등 +902522111343
}

ÖZ

Küresel ısınmanın etkileri her geçen gün çarpıcı boyutlara ulaşarak doğal kaynaklar arasında yer alan ve canlıların yaşamının temeli olan suyun varlığını tehlikeye sokmaktadır. Su kaynaklarının korunması, ekolojik dengenin sürdürülebilirliğinin yanı sıra suyun gelecek nesillere sorunsuz bir şekilde aktarılmasına da katkı sağlamaktadır. Tüm dünyada mevcut su kaynaklarının azalması nedeniyle suyun her alanda akılı bir şekilde yönetilmesi ve kullanılması gerekmektedir. Son yıllarda suyun yoğun kullanıldığı tarımsal alanlardan biri olarak karşımıza çıkan peyzaj tasarımlarındaki sulamalarda doğayla uyumlu ve sürdürülebilir bir uygulama olarak su tasarrufunu benimseyen bir yaklaşım olan kurakçıl peyzaj çalışmalarının önemi giderek artmaktadır. Çalışmada, çevresel ve fiziki analiz işlemlerinin gerçekleştirilmesi amacıyla alan kullanımları çıkartııp mevcut bitki türleri belirlenerek kurakçıl peyzaj açısından değerlendirilme durumları tespit edilmiştir. Sürdürülebilir çevre yaklaşımı ile bölge ekolojisine uygun, kuraklığa dayanıklı ve özellikle doğal türlerin yer aldığı alternatif bitkiler tespit edilerek "Muğla-Sarıgerme Halk Plajı”nda kurakçıl peyzaj ilkeleri doğrultusunda örnek bir bitkisel tasarım projesinin hazırlanması hedeflenmiştir. Ayrıca bu araştırmada, kuraklığa dayanıklı bitki türlerinin seçilmesi ile sürdürülebilir peyzaj uygulamaları kapsamında bitkisel tasarım projesinin hazırlanması sonucu gerçekleştirilecek diğer kurakçıl peyzaj tasarım çalışmaları için öncülük etmek de amaçlanmıştır.

Anahtar Kelimeler: Kurakçıl peyzaj, suyun etkin kullanımı, su tasarrufu, sürdürülebilirlik

\section{Herbal Applications in Xeriscape Studies: The Case Study of Muğla-Sarıgerme Public Beach, Turkey}

\begin{abstract}
The effects of global warming reach striking levels every day and endanger the existence of water, which is among the natural resources and which is the basis of life. The protection of water resources contributes not only to the sustainability of ecological balance but also to the smooth transfer of water through future generations. Due to the decrease in the current water resources all over the world, it is necessary to manage and use water rationally in every field. In the recent years, the importance of xeriscape works, which is an approach that adopts water saving as an environmentally compatible and sustainable practice in irrigation in landscape designs, one of the agricultural areas where water is used extensively, is increasing gradually. In order to carry out environmental and physical analysis in the study, by determining the field uses and the existing plant species, the conditions of evaluation in terms of xeriscape were revealed. It was aimed to prepare an exemplary herbal design project in accordance with the principles of xeriscape in "Muğla-Sarıgerme Public Beach" by identifying alternative plants appropriate for regional ecology, resistant to drought and involving especially natural species with sustainable environment approach. Besides, it was also aimed to pioneer other xeriscape design studies to be carried out because of preparing an herbal design project within the scope of sustainable landscaping applications with the selection of the plant species resistant to drought.
\end{abstract}


Keywords: Xeriscape, effective use of water, water saving, sustainability

\section{Giriş}

Günümüze kadar hız kesmeden ilerleyen sanayileşme, teknolojik gelişmeler, artan kentleşme ve nüfusun etkisi, küresel ısınmanın ciddi bir şekilde hissedilmesine neden olmuştur. Dünyayı etkileyen küresel ısınma; iklimsel değerleri değiştirerek doğal dengeyi bozup yaşam için gerekli temel kaynaklardan olan suyun varlığını tehdit etmektedir (Bozoğlu ve ark., 2003; Appenzerler ve Dimick, 2004; Ersoy, 2006; Karaman ve Gökalp, 2010). Canlıların yaşamını doğrudan etkileyen su kaynaklarının azalması doğanın sürdürülebilirliğini bozarak; ormansızlaşma, kuraklık, tarım ürünlerinin çeşitliliğinde azalma, doğal afetler ile atmosferik olayların artması, erozyonun şiddetlenmesi ve verimin düşmesi gibi birçok soruna neden olmaktadır (Öztürk, 2002; Atalık, 2006; Ersoy, 2006; Koçer ve ark., 2009; Karaman ve Gökalp, 2010). Yaşamın her alanında suya intiyacın artması sonucu su kaynaklarında görülen azalma, suyun öneminin daha iyi anlaşılması gerektiği konusunu gündeme getirmiştir.

Alternatifsiz ve üretilmesi mümkün olmayan doğal kaynaklardan suyun korunması ve devamlılığının sağlanması, hem ekolojik denge hem de suyun gelecek nesillere aktarılması açısından büyük önem taşımaktadır (Karaman ve Gökalp, 2010). Bu bağlamda su kaynaklarının fiziksel, sosyal, ekonomik ve çevresel açıdan bir bütün halinde yönetilmesi, korunması ve kullanımının geliştirilmesi gerekmektedir (Aküzüm ve Çakmak, 2008; Ertop, 2009; Karaman ve Gökalp, 2010; Baykan ve Birişçi, 2013; Metin ve Koçan, 2020).

Dünyada kullanılabilir suyun büyük bir bölümü tarımsal alanlarda değerlendirilmektedir. Bu doğrultuda da tarımsal alanlar içinde en yoğun su tüketimi olan sahalardan biri olarak peyzaj tasarım çalışmaları karşımıza çıkmaktadır. Günümüzde değişen iklim koşulları nedeniyle artan sıcaklıklar ve az miktarda gerçekleşen yağışlar sonucu ortaya çıkan kuraklıklar, bitkilerin yaşamsal faaliyetlerini doğrudan etkilediğinden peyzaj düzenlemelerinde suyun daha akılcı, stratejik ve verimli kullanımını gündeme getirmiştir (Barış, 2007). Bu bağlamda sayıları her geçen gün artarak önem kazanan özellikle kurak bölgelerdeki peyzaj düzenleme çaIışmalarında "Xeriscape" yani kurakçıl peyzaj yaklaşımı gibi su etkin peyzaj tasarımlarının kullanılması ve doğal bitki türlerinin tercih edilmesi gibi uygulamalar su tasarrufu açısından oldukça dikkat çekmektedir (Atik ve Karagüzel, 2007; Barış, 2007; Çorbacı ve ark., 2011a).
"Kurakçıl Peyzaj”, klasik peyzaj düzenleme anlayışından farklı olarak "Su Etkin Peyzaj Düzenlemeleri" başlığı altında toplanan "Az Su Kullanımı", "Suyun Akılcı Kullanımı" ve "Doğal Peyzaj Düzenleme" gibi su tasarrufunu benimseyen bir yaklaşım olarak ortaya çıkmıştır (Weinstein, 1999; Barış, 2007). Kurakçıl peyzaj anlayışı doğrultusunda gerçekleştirilen tasarım çalışmalarının; su tasarrufu sağlayan, çevreyle uyumlu, görsel kalite ve estetiği koruyan, bakım masrafları ve işlemlerini azaltan, uygulandığı alanda su ihtiyacı düşük olan doğal türlerin de tercih edilmesiyle adaptasyon sorunu yaşanmayan ve kimyasal uygulamaları en aza indirebilen bir perspektife sahip olduğu da birçok çalışmada belirtilmektedir (Aklanoğlu, 2007; Barış, 2007; Tülek, 2008; Ertop, 2009; Çakmak ve Gökalp, 2011; Çorbacı ve ark., 2011b; Bayramoğlu, 2013; Bayramoğlu ve ark., 2013; Elevitch ve Wilkinson, 2014; Bayramoğlu ve Demirel, 2015; Güvenç ve Demiroğlu, 2016; Çetinkale Demirkan ve Akat, 2017).

Araştırmada, özellikle mevsimsel kuraklığın yoğun bir şekilde hissedildiği “Muğla-Sarıgerme Halk Plajı"nın alan kullanımları ortaya konularak mevcut bitki türleri tespit edilip kurakçıl peyzaj açısından değerlendirilerek sürdürülebilir çevre yaklaşımı kapsamında bölge ekolojisine uygun ve kuraklığa dayanıklı alternatif türlerin belirlenmesi sonucu kurakçıl peyzaj ilkeleri doğrultusunda örnek bir bitkisel tasarım projesinin hazırlanması hedeflenmiştir. Ayrıca bu çalışmanın benzer ekolojik özelliklere sahip alanlarda gerçekleştirilmesi planlanan diğer kurakçıl peyzaj tasarımlarında, suyun sürdürülebilirliğinin sağlanmasındaki uygulamalar noktasında yol gösterici olması da hedeflenmektedir.

\section{MATERYAL VE YÖNTEM}

Muğla, Akdeniz ve Ege Bölgeleri arasında bulunduğundan her iki bölgenin iklim özelliğini taşıyarak ekolojik açıdan zengin bir flora ve faunaya sahip, kış ayları ılık ve bol yağışlı, yaz ayları ise kurak ve sıcak geçen bir ildir (Kazan, 2007; Akan ve ark., 2018). Araştırmanın yürütüldüğü Sarıgerme; Muğla ilinin Ortaca ilçesinde yer almakta olup, $7 \mathrm{~km}$ uzunluğundaki doğa harikası kumsalının denizle bütünleşmesiyle eşsiz görsel bir güzellik sunmaktadır (Şekil 1) (Anonim, 2019).

Muğla-Sarıgerme Halk Plajı" yerli ve yabancı turistlere denize girme, kamp yapma ve günü birlik konaklama olanağı sağlamak amacıyla hizmet vermektedir (Şekil 2). 


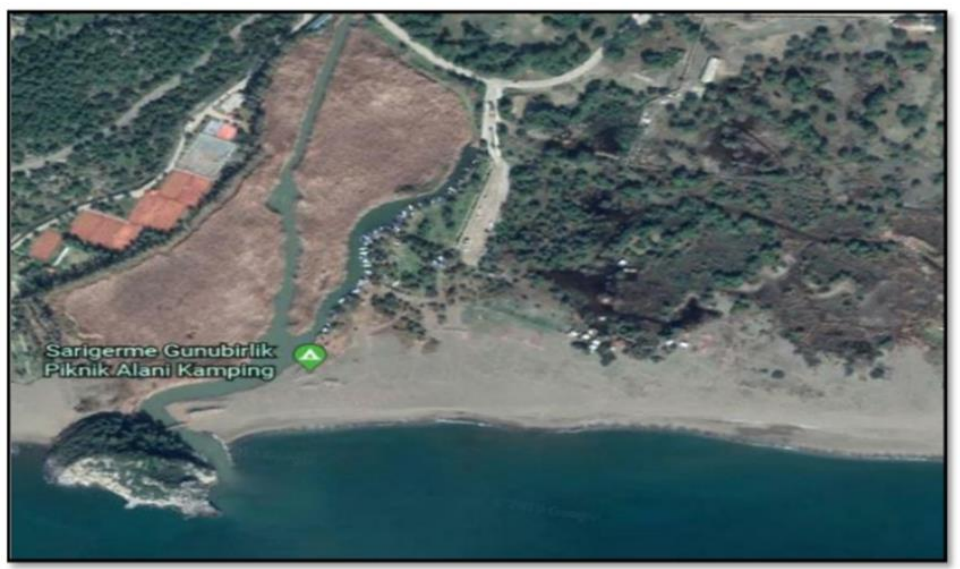

Şekil 1. Ortaca ilçesi "Muğla-Sarıgerme Halk Plajı" uydu görüntüsü

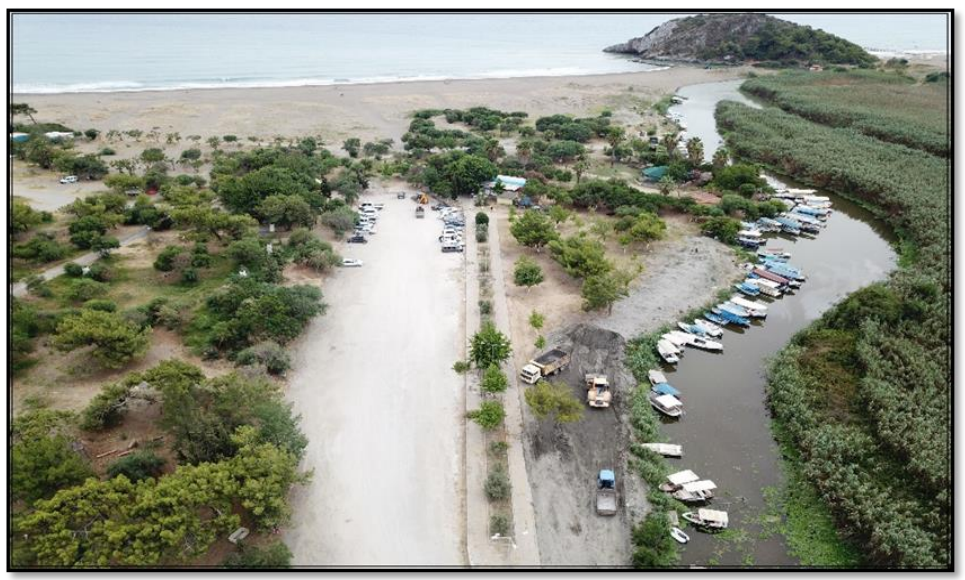

Şekil 2. Çalışma alanından bir görüntü

Ortaca Belediyesi, plaj alanının daha aktif bir hale getirilip hem tesis hem de çevresel anlamda eksikliklerinin giderilmesi amacıyla çalışma başlatarak hazırladıkları yapısal sert zemin projesi dikkate alınarak su tasarrufuna katkı sağlayan kurakçıl peyzaj ilkeleri doğrultusunda bitkisel tasarım projesinin yapılmasını talep etmiştir. Bu bağlamda, peyzaj tasarım projesinin hazırlık aşamasında çalışma alanın rölövesi üzerinden mevcut durum yerinde incelenerek alana ait toplanan tüm bilgiler doğrultusunda çevresel ve fiziki analiz işlemleri gerçekleştirilmiştir. Çalışma alanı kullanım amaçlarına göre gruplandırılarak var olan tüm veriler "Netcad 5.2" programındaki çizim ve hesap modülü yardımıyla tespit edilmiştir. Araştırma alanında var olan bitki türleri belirlenerek kurakçıl peyzaj yaklaşımı doğrultusunda; su istekleri, anavatan ve yayılış alanları; Çorbacı ve ark., (2011a), Tülek ve Barış (2011), Baykan ve Birişçi (2013), Yazıcı ve ark., (2014), Bayramoğlu (2016), Güvenç ve Demiroğlu (2016), Çetin ve Mansuroğlu (2018) ile Akat ve Çöp (2018) tarafından yapılan çalışmalar kapsamında irdelenmiştir.

Ayrıca çalışma sahasında bölge ekolojisine uygun, kuraklığa dayanıklı ve özellikle doğal türlerin yer aldığı alternatif bitki türlerinin tespit edilmesi ile benzer ekolojik koşullara sahip alanlar için farklı bir bakış açısı sunulması adına kurakçıl peyzaj ilkeleri doğrultusunda Autocad 2014 programı ile dijitalleştirilerek bir bitkisel tasarım projesi oluşturulmuştur (Şekil 3). 


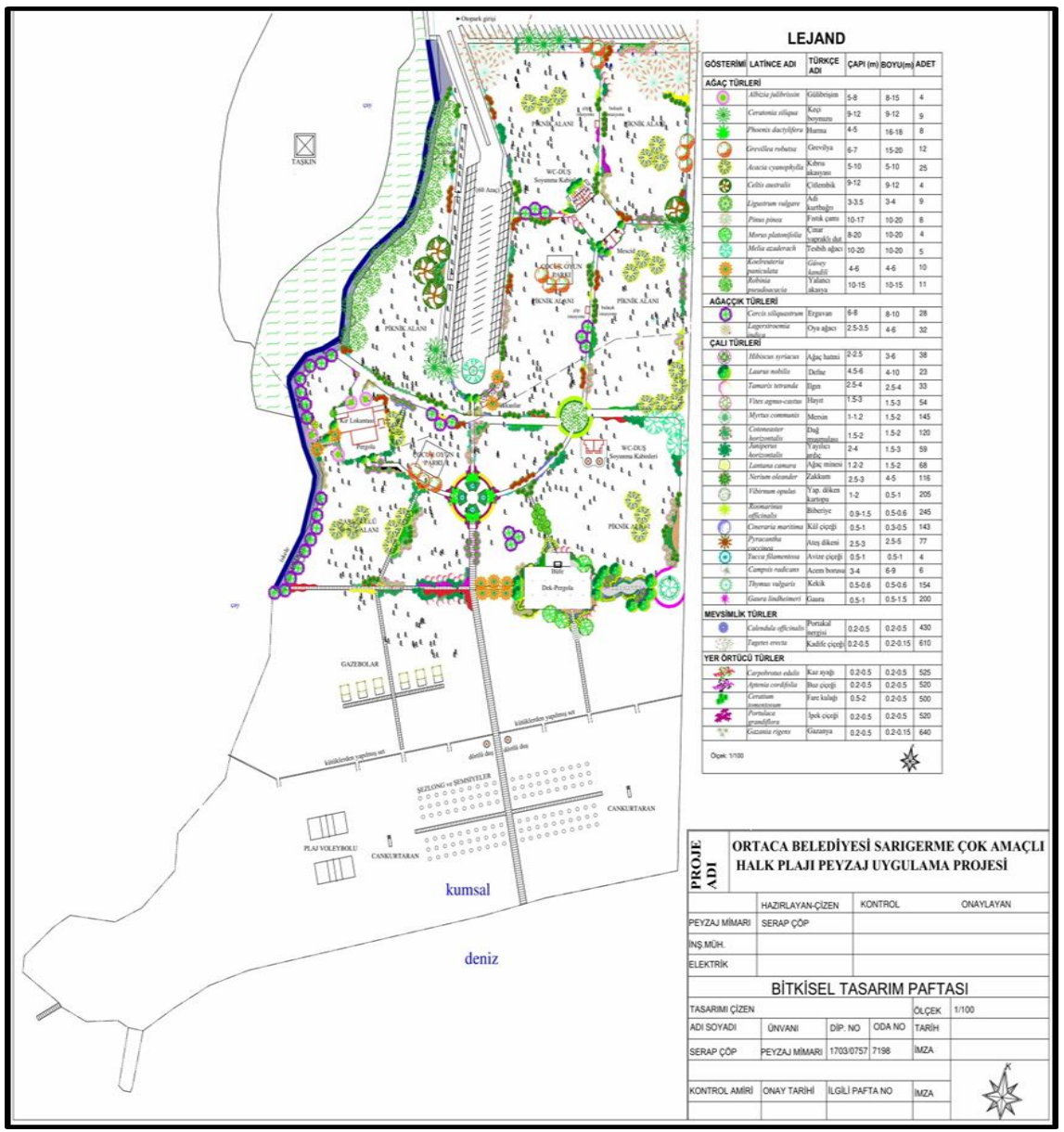

Şekil 3. Kurakçıl peyzaj ilkeleri doğrultusunda hazırlanmış bitkisel tasarım projesi

\section{ARAŞTIRMA BULGULARI VE TARTIŞMA}

Çalışma sahasının mevcut durumunun değerlendirilmesi ve bölge ekolojisinin belirlenmesi amacıyla öncelikle toprak tahlili sonuçları ile iklim koşullarına yönelik veriler alınmıştır. Bu doğrultuda araştırma alanının toprak özellikleri incelendiğinde; Ortaca Belediyesi'nden edinilen bilgilere göre sahaya dolgu toprağının taşınmış olması sonucu bazı değerlerin zaman içinde değişikliğe uğraması nedeniyle sahil kuşağını temsil etmeyen toprak analiz sonuçlarıyla karşılaşıldığı görülmektedir (Tablo 1).
Tablo 1. Çalışma alanına ait toprak analiz sonuçları

\begin{tabular}{lr}
\hline Analizler & Sonuç \\
\hline Bünye & Kumlu Tın \\
Toplam Tuz (\%) & 0,088 \\
pH & 7,81 \\
Kireç (\%) & 27,26 \\
Organik Madde (\%) & 1,71 \\
Toplam Azot (\%) & 0,09 \\
Alınabilir Fosfor (ppm) & 10,00 \\
Alınabilir Potasyum (ppm) & 67,99 \\
Alınabilir Kalsiyum (ppm) & 4978,87 \\
Alınabilir Magnezyum (ppm) & 326,39 \\
Alınabilir Sodyum (ppm) & 23,57 \\
Alınabilir Demir (ppm) & 21,76 \\
Alınabilir Bakır (ppm) & 0,85 \\
Alınabilir Mangan (ppm) & 16,38 \\
Alınabilir Çinko (ppm) & 0,49
\end{tabular}

2019 yılına ait çalışma alanının yağış değerleri incelendiğinde; yıllık toplam yağış miktarının $1364 \mathrm{~mm}$ ve ortalama yağış miktarının ise 113,6 mm olduğu gözlemlenerek bu yağışların en yoğun kış aylarında gerçekleştiği izlenmektedir (Tablo 2). İklimsel sınıflandırmada, genel 
olarak yıllık ortalama yağışın 250 mm'den az olduğu bölgelerin kurak ve $250-500 \mathrm{~mm}$ civarındaki alanların ise yarı kurak iklim özelliği taşıdığı bildirilmektedir (Kapluhan, 2013). Bu bağlamda araştırma alanının yıllık ortalama yağış miktarı açısından kurak sınıfta yer aldığının tespit edilmesinin yanı sıra yaz aylarındaki yağış miktarının 36,4 mm değeri ile düzensiz ve kısa süreli olarak gerçekleştiği de saptanmıştır. Ayrıca araştırma alanının sıcaklık verilerine bakıldığında; en düşük sıcaklığın $0,3^{\circ} \mathrm{C}$ ile Ocak ve en yüksek sıcaklık değerinin ise $38,7^{\circ} \mathrm{C}$ ile Ağustos ayında görüldüğü Tablo 2'den takip edilmektedir. Yaz aylarında gerçekleşen yağışların düşüklüğüne ilaveten sıcaklığın bu aylarda yüksek seyretmesi ve nem oranlarının ise düşük olması, mevsimsel kuraklığın ciddi bir şekilde hissedildiğinin göstergesi olarak kabul edildiğinde; çalışma alanında suyun etkin kullanımını benimseyen bir bitkisel tasarım projesinin hazırlanması daha fazla önem kazanmaktadır. Bu doğrultuda çalışma alanı için gerçekleştirilmesi planlanan kurakçıl peyzaj tasarımının, sürdürülebilir yeşil kentsel dokunun oluşturulmasına da katkı sağlayacağı düşünülmektedir.

Araştırma alanın daha iyi analiz edilebilmesi adına; bitkisel tasarımın gerçekleştirileceği saha kullanım amaçlarına göre gruplandırılarak her birinin kapladığı alan ve dağılımları Tablo 3'de verilmiştir.

Tablo 2. Çalışma alanının 2019 yılına ait iklim verileri

\begin{tabular}{lrrrr}
\hline Aylar & $\begin{array}{c}\text { Yağış Ortalaması } \\
(\mathbf{m m})\end{array}$ & $\begin{array}{c}\text { Nisbi Nem Or- } \\
\text { talaması (\%) }\end{array}$ & $\begin{array}{c}\text { Maksimum } \\
\text { Sıcaklık ('C) }\end{array}$ & $\begin{array}{c}\text { Minimum } \\
\text { Sıcaklık ('C) }\end{array}$ \\
\hline Ocak & 406,3 & 73,2 & 17,1 & $-0,3$ \\
Şubat & 102,2 & 73,3 & 23,0 & 3,9 \\
Mart & 94,2 & 69,9 & 23,3 & 3,7 \\
Nisan & 102,0 & 72,6 & 26,2 & 6,7 \\
Mayıs & 6,8 & 70,8 & 34,4 & 8,4 \\
Haziran & 16,6 & 68,7 & 38,4 & 12,2 \\
Temmuz & 19,8 & 65,1 & 38,6 & 16,6 \\
Ağustos & 0,0 & 66,8 & 38,7 & 18,8 \\
Eylül & 62,5 & 66,1 & 34,9 & 14,3 \\
Ekim & 63,4 & 74,1 & 31,9 & 10,3 \\
Kasım & 117,8 & 80,4 & 28,0 & 6,7 \\
Aralık & 372,4 & 76,8 & 21,1 & 3,3 \\
\hline Toplam & 1364,0 & & & \\
\hline
\end{tabular}

Tablo 3. Çalışmadaki mevcut alanların kullanım amaçları ve dağılımları

\begin{tabular}{l|rr}
\hline Kullanım Amaçları & Alan $\left.\mathbf{( m}^{\mathbf{2}}\right)$ & Dağılım Oranları (\%) \\
\hline Yeşil ve Ormanlık Alanlar & 34802,30 & 39,22 \\
Kaldıımlar & 478,13 & 0,53 \\
Araç Yolları & 1783,23 & 2,00 \\
Bina Oturum Alanları & 265,42 & 0,29 \\
Toprak Alanlar & 14782,13 & 16,66 \\
Kumsal Alanlar & 34037,19 & 38,36 \\
Otopark Alanları & 2574,84 & 2,90 \\
\hline Toplam Çalışma Alanı & $\mathbf{8 8 7 2 3 , 2 7}$ & $\mathbf{1 0 0 , 0 0}$ \\
\hline
\end{tabular}

Peyzaj tasarım çalışmalarında bitkiler, en önemli tasarım unsurları arasında yer alarak estetik ve fonksiyonel mekânların oluşturulmasında büyük rol oynayıp yapısal elemanların yumuşatılması ve görsel etkinliklerinin arttırılmasında önemli katkılar sağlamaktadır (Acar ve ark., 2003; Dönmez ve ark., 2016). Bu doğrultuda çalışma alanındaki mevcut bitki grupları değerlendirildiğinde; 790 bitkiye ait 24 türün; \%50'sinin ağacı, \%4,17'sinin ağaççık, \% 29,16'sının çalı ve \%16,67'sinin ise meyve ağacı türü olduğu tespit edilerek tüm bu türlerin $\% 45,83$ 'lük bir oran ile 611 'inin ise doğal bitkilerden oluştuğu saptanmıştır (Tablo 4). Araştırma sahasındaki mevcut bitki türlerinin yaklaşık yarısının doğal tür olması ve toplam bitki varlığı içinde \%77,34'lük bir oran ile fazla bitki bulunmasının, adaptasyon ve su tasarrufuna katkı sağlanması açısından kurakçıl peyzaj ilkeleri doğrultusunda bir avantaj oluşturmaktadır. Günümüzde açık yeşil alanların oluşturulması kadar sürdürülebilirliğinin sağlanması amacıyla bakım maliyetlerinin de yüksek olması, kurakçıl peyzaj yaklaşımının önemini daha fazla arttırmaktadır. Bu bağlamda bitki seçimlerinde, alandaki mevcut bitki türlerinin belirlenmesinin ardından hazırlan- 
Kurakçıl Peyzaj Çalışmalarında Bitkisel Uygulamalar: Muğla-Sarıgerme Halk Plajı Örneği

ması planlanan bitkisel tasarım projesinde kurakçıl peyzaj yaklaşımı doğrultusunda doğal türlere daha fazla yer verilmesinin olumlu sonuçlar ortaya koyacağı düşünülmektedir.

Tablo 4. Çalışma alanındaki bitki gruplarına göre dağılımlar ve doğal türler

\begin{tabular}{l|rrrr}
\hline Bitki Grupları & $\begin{array}{c}\text { Bitki Türü Sayısı } \\
\text { (adet) }\end{array}$ & $\begin{array}{c}\text { Tür Sayısına } \\
\text { Göre Dağıım (\%) }\end{array}$ & $\begin{array}{c}\text { Bitki Sayısı } \\
\text { (adet) }\end{array}$ \\
\hline Ağaç & 12 & 50,00 & 654 \\
Ağaçıcıklar & 1 & 4,17 & 1 \\
Çalılar & 7 & 29,16 & 73 \\
Meyve Ağaçları & 4 & 16,67 & 62 \\
\hline Toplam & $\mathbf{2 4}$ & $\mathbf{1 0 0 , 0 0}$ & $\mathbf{7 9 0}$ \\
\hline Doğal türler & $\mathbf{1 1}$ & $\mathbf{4 5 , 8 3}$ & $\mathbf{6 1 1}$ \\
\hline
\end{tabular}

Çalışma sahasındaki mevcut bitki türlerinin yaklaşık $\% 8$ 'lik bir kısmı olan 2 türünün su ihtiyacının yüksek, geriye kalanların ise yarı yarıya su isteğinin az ve orta düzeydeki türlerden olması, kurakçıl peyzaj bakımından olumlu bir durumdur (Tablo 5). Ayrıca alanda az miktardaki meyve türü yerel halk tarafından ürünlerinden yararlanmak amacı ile dikilmiş olup, kurakçıl peyzaj yaklaşımı açısından planlama ve tasarım aşamasında var olan bu gelişmiş bitkilerin sökülmemesi yönünde karar alınmıştır. Çakar ve ark. (2018), kurakçıl peyzaj kapsamında gerçekleştirilen bitkisel tasarım çalışmalarında; sahadaki belli bir gelişme seviyesine ulaşmış mevcut bitkilerin, ekstra sulama ve bakım uygulaması gerektirmemesi nedeniyle alandaki yerlerinde korunmasına özen gösterilmesi gerektiğini bildirmiştir. Yürütülen araştırmada da, sahadaki gelişmiş bitkilerin alanda korunmasının hem adaptasyon süreci hem de su tasarrufuna katkı sağlama anlamında literatür ile benzerlik göstererek kurakçıl peyzaj yaklaşımı bakımından doğru bir uygulamanın gerçekleştirildiğini ortaya koymaktadır. Ayrıca çaIışma alanında mevsimlik süs bitkileri ile yer örtücülerin bulunmadığı ve su temininde yaşanan sıkıntıların yanı sıra bakım işlemlerinin zorluğuna bağlı olarak çim türlerinin de tercih edilmediği gözlemlenmiştir.

Araştırma sahasındaki mevcut bitki gruplarının kendi içindeki su isteklerine göre dağılımları irdelendiğinde; 12 ağaç türünün \%58,33'ü, 7 çalı türünün $\% 42,85$ 'i, ağaççık grubunun tamamının az ve meyve ağaçlarında ise 4 türün \%75'inin orta su isteğine sahip olduğu görülmektedir (Şekil 4).

Tablo 5. Çalışma alanındaki bitki türlerinin su isteklerine göre gruplandırılması

\begin{tabular}{l|rrr|r}
\hline Bitki Grupları & \multicolumn{1}{c}{$\begin{array}{c}\text { Su isteği } \\
\text { yüksek (adet) }\end{array}$} & $\begin{array}{c}\text { Su isteği } \\
\text { orta (adet) }\end{array}$ & $\begin{array}{c}\text { Su isteği } \\
\text { az (adet) }\end{array}$ & $\begin{array}{c}\text { Bitki Tür Sayısı } \\
\text { (adet) }\end{array}$ \\
\hline Ağaç & 1 & 4 & 7 & 12 \\
Ağaççıklar & 0 & 0 & 1 & 1 \\
Çalılar & 0 & 4 & 3 & 7 \\
Meyve Ağaçları & 1 & 3 & 0 & 4 \\
\hline Toplam & $\mathbf{2}$ & $\mathbf{1 1}$ & $\mathbf{1 1}$ & $\mathbf{2 4}$ \\
\hline
\end{tabular}

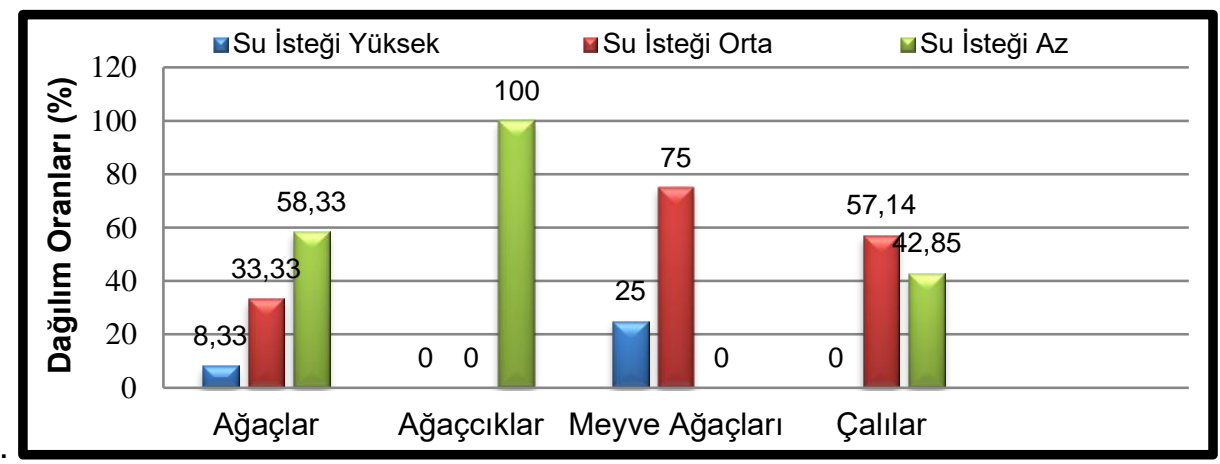

Şekil 4. Çalışmadaki mevcut bitki gruplarının su isteklerine göre dağılımları 
Çalışma alanındaki mevcut bitkiler gruplandırılarak tür isimleri, su istekleri ve anavatanları ile yayılış alanları Tablo 6'da sunulmuştur (Çorbacı ve ark., 2011a; Tülek ve Barış, 2011; Baykan ve Birişçi, 2013; Yazıcı ve ark.,
2014; Güvenç ve Demiroğlu, 2016; Akat ve Çöp, 2018; Çetin ve Mansuroğlu, 2018).

Tablo 6. Çalışma alanındaki mevcut bitki türleri, su istekleri ve anavatanı/yayılış alanları

\begin{tabular}{|c|c|c|c|}
\hline & BITKI GRUPLARI & SU ISTEĞ| & ANAVATANI / YAYILIŞ ALANLARI \\
\hline & AĞAÇ TÜRLERİ /Adet & & \\
\hline 1 & Ailanthus altissima (Kokarağaç) /1 & $A z$ & Çin, Kuzey Türkiye \\
\hline 2 & Phoenix dactylifera (Hurma) /1 & $\mathrm{Az}$ & Orta Doğu \\
\hline 3 & Acacia cyanophylla (Kıbrıs Akasyası) /287 & Orta & Akdeniz Ülkeleri \\
\hline 4 & Washingtonia filifera (Palmiye) /65 & $A z$ & ABD, Meksika, Batı ve Güney Türkiye \\
\hline 5 & Robinia pseudoacacia (Yalancı Akasya) /9 & Orta & Kuzey Türkiye, Kuzey Amerika \\
\hline 6 & Pinus brutia (Kızılçam) /210 & $\mathrm{Az}$ & Doğu Akdeniz, Türkiye, İtalya \\
\hline 7 & Platanus orientalis (Doğu Çınarı) /1 & Yüksek & $\begin{array}{l}\text { Güneydoğu Avrupa, Batı Asya, Himalaya, } \\
\text { Türkiye }\end{array}$ \\
\hline 8 & Melia azaderach (Tespih Ağacı) /23 & Orta & Uzak Doğu, Güney Avrupa, Hindistan, Çin \\
\hline 9 & Liquidamber orientalis (Sığla) /27 & Orta & Türkiye \\
\hline 10 & Cupressus sempervirens (Adi Servi) /21 & $A z$ & Güney Avrupa, Türkiye, İran \\
\hline 11 & Ulmus glabra (Karaağaç) /8 & Orta & $\begin{array}{l}\text { Avrupa-Sibirya, Türkiye, Kafkasya, Kuzey } \\
\text { İran }\end{array}$ \\
\hline 12 & Casuarina equisetifolia (Demir Ağacı) /1 & $\mathrm{Az}$ & Avusturalya \\
\hline & AĞAÇÇIK TÜRLERI /Adet & & \\
\hline 13 & Cercis siliquastrum (Erguvan) /1 & $\mathrm{Az}$ & Akdeniz Ülkeleri \\
\hline & MEYVE TÜRLERI /Adet & & \\
\hline 14 & Ficus carica (İncir) /5 & Orta & Türkiye, Türkmenistan, Tacikistan \\
\hline 15 & Morus alba (Dut) /33 & Yüksek & Çin, Japonya, Uzak Doğu, Türkiye \\
\hline 16 & Olea europaea (Zeytin) /23 & Orta & Akdeniz Ülkeleri, Asya \\
\hline 17 & Punica granatum (Nar) /1 & Orta & Güneydoğu Avrupa, Güney Asya, Türkiye \\
\hline & ÇALI TŬRLERI IAdet & & \\
\hline 18 & Euonymus japonica (Taflan) /1 & Orta & Çin, Japonya, Asya \\
\hline 19 & Nerium oleander (Zakkum) /60 & $\mathrm{Az}$ & Akdeniz Ülkeleri \\
\hline 20 & Myrtus communis (Mersin) /2 & $\mathrm{Az}$ & Güney Avrupa, Türkiye \\
\hline 21 & Hibiscus syriacus (Ağaç Hatmi) /1 & Orta & Pakistan, Çin, Hindistan \\
\hline 22 & Thuja occidentalis (Batı Mazısı) /3 & Orta & Amerika, Kanada \\
\hline 23 & Laurus nobilis (Defne) /5 & Orta & Akdeniz Ülkeleri \\
\hline 24 & Vitex agnus-castus (Hayıt) /1 & $A z$ & $\begin{array}{l}\text { Türkiye, Güney Avrupa, Kırım, Batı Suriye, } \\
\text { Kuzey Afrika }\end{array}$ \\
\hline
\end{tabular}

Araştırma sahasındaki mevcut bitki varlığına bakıldığında; kurakçıl peyzaj ilkeleri doğrultusunda alanda doğal bitki türlerinin yanı sıra su isteği az ve orta düzeydeki bitkilerin yoğun olarak bulunmasının, su tasarrufuna katkı sağlaması ile birlikte gerçekleştirilmesi planlanan kurakçı peyzaj tasarımı açısından avantaj oluşturduğu gibi literatür ile benzerliklerin ortaya konulduğunun da bir göstergesidir. Kurakçıl peyzaj tasarımlarında kültür bitkilerinin kullanımı söz konusu olduğunda; su isteği az, kuraklığa dayanıklı, hastalık ve zararlılara karşı dirençli, ekstra bir bakıma intiyaç duymayan ve hassas olmayan bitki türlerinin seçilmesine yer verilmesi gerekmektedir (Eşbah, 2010; Taner, 2010). Ayrıca bölgedeki doğal bitkilerin yörenin ekstrem iklim koşullarına daha dayanıklı olması nedeniyle kurakçıl peyzaj çalışmalarındaki bitki tercihlerinde ön planda tutulması da su tasarrufu ve adaptasyon açısından önemlidir (Çorbacı ve ark., 2011a; Gül ve ark., 2012; Baykan ve Biriş̧̧i, 2013).

$\mathrm{Bu}$ doğrultuda hazırlanması planlanan bitkisel tasarım projesi için bölgenin doğal türlerine ilaveten kültür bitkilerinden yoğunluklu olarak su intiyacı az olan bitkiler ile insan sirkülasyonun fazla olduğu yerlerde ise orta düzeyde su tüketimine sahip türlerin tercih edilmesine dikkat edilmiştir. Bitkisel tasarım projesinde bölgenin doğal bitkilerine öncelikli olarak yer verilmesinin yanı sıra kurakçıl peyzaj yaklaşımına uygun ilave türlerin de dâhil edildiği projede kullanılan bitki listesi literatür doğrultusunda belirlenerek Tablo 7'de verilmiştir (Çorbacı ve ark., 2011a; Tülek ve Barış, 2011; Baykan ve Birişçi, 2013; Yazıcı ve ark., 2014; Bayramoğlu, 2016; Güvenç 
ve ark., 2016; Akat ve Çöp, 2018; Çetin ve Mansuroğlu,

2018).

Tablo 7. Bitkisel tasarım projesinde önerilen bitki türlerinin su isteği ve anavatanı/yayılış alanları

\begin{tabular}{|c|c|c|c|}
\hline & BITTKI GRUPLARI & SU ISTEĞ| & ANAVATANI/YAYILIŞ ALANLARI \\
\hline & AĞAÇ TÜRLERI /Adet & & \\
\hline 1 & Phoenix dactylifera (Hurma) /8 & $A z$ & Orta Doğu \\
\hline 2 & Acacia cyanophylla (Kıbrıs Akasyası) /25 & Orta & Akdeniz Ülkeleri \\
\hline 3 & Robinia pseudoacacia (Yalancı Akasya) /11 & Orta & Kuzey Anadolu, Kuzey Amerika, Akdeniz Ülkeleri \\
\hline 4 & Melia azaderach (Tespih Ağacı) /5 & Orta & Uzak Doğu, Güney Avrupa, Hindistan, Çin \\
\hline 5 & Albizia julibrissin (Gülibrişim) /4 & Orta & Asya, Kuzey Doğu Anadolu, Kuzey İran \\
\hline 6 & Celtis orientalis (Çitlenbik Ağacı) /4 & $\mathrm{Az}$ & Güney Avrupa, Kuzey Afrika, Türkiye \\
\hline 7 & Ceratonia siliqua (Keçiboynuzu) /9 & $A z$ & Akdeniz Ülkeleri \\
\hline 8 & Koelreuteria paniculata (Güvey Kandili) /10 & $\mathrm{Az}$ & Asya, Çin \\
\hline 9 & Morus platonifolia (Çınar Yapraklı Dut) /4 & Orta & Çin, Japonya, Uzak Doğu \\
\hline 10 & Pinus pinea (Fıstık Çamı) /8 & $\mathrm{Az}$ & Akdeniz Ülkeleri, Portekiz \\
\hline 11 & Grevillea robusta (Grevilya) /12 & $A z$ & Avusturalya \\
\hline \multirow[t]{2}{*}{12} & Ligustrum vulgare (Adi Kurtbağrı) /9 & Orta & $\begin{array}{l}\text { Kuzey Türkiye, Orta Anadolu, Fas, Avrupa, Kaf- } \\
\text { kasya, Kuzey İran }\end{array}$ \\
\hline & AĞAÇÇIK TÜRLERİ /Adet & & \\
\hline 13 & Cercis siliquastrum (Erguvan) /28 & $A z$ & Akdeniz Ülkeleri \\
\hline \multirow[t]{2}{*}{14} & Lagerstroemia indica (Oya Ağacı) /32 & $\mathrm{Az}$ & Güney Çin, Güney Asya \\
\hline & ÇALI TÜRLERI /Adet & & \\
\hline 15 & Nerium oleander (Zakkum) /116 & $A z$ & Akdeniz Ülkeleri \\
\hline 16 & Myrtus communis (Mersin) /145 & $\mathrm{Az}$ & $\begin{array}{l}\text { Akdeniz Ülkeleri, Güney Avrupa, Kuzey Afrika, } \\
\text { Batı Suriye, Kıbrıs, Orta Asya }\end{array}$ \\
\hline 17 & Hibiscus syriacus (Ağaç Hatmi) /38 & Orta & Pakistan, Çin, Hindistan \\
\hline 18 & Laurus nobilis (Defne) /23 & Orta & Akdeniz Ülkeleri \\
\hline 19 & Vitex agnus-castus (Hayıt) /54 & $\mathrm{Az}$ & $\begin{array}{l}\text { Akdeniz Ülkeleri, Güney Avrupa, Kırım, Batı Su- } \\
\text { riye, Kuzey Afrika }\end{array}$ \\
\hline 20 & Gaura lindheimeri (Gaura) /200 & Orta & Avrupa, Kuzey Amerika \\
\hline 21 & Cotoneaster horizontalis (Dağ Muşmulası)/120 & Orta & Çin, Asya, Avrupa, Afrika \\
\hline 22 & Lantana camara (Ağaç Minesi) /68 & $\mathrm{Az}$ & Güney Amerika, Tropikal Asya \\
\hline 23 & Thymus vulgaris (Kekik) /154 & $\mathrm{Az}$ & Avrupa, Kuzey Afrika, Asya, Akdeniz Ülkeleri \\
\hline 24 & Campsis radicans (Acemborusu) /6 & $\mathrm{Az}$ & ABD, Florida, Teksas \\
\hline 25 & Yucca filamentosa (Avize Çiçeği) /4 & $A z$ & $\mathrm{ABD}$ \\
\hline 26 & Pyracantha coccinea (Ateş Dikeni) /77 & $A z$ & Asya, Güney Avrupa, Kırım \\
\hline 27 & Cineraria maritima (Kül Çiçeği) /143 & $\mathrm{Az}$ & Güney Orta Avrupa, Batı Akdeniz \\
\hline 28 & Rosmarinus officinalis (Biberiye) /245 & $A z$ & $\begin{array}{l}\text { Güney Afrika, Akdeniz Ülkeleri, Fransa, İspanya, } \\
\text { ABD, Çin, Avustralya }\end{array}$ \\
\hline 29 & Vibirnum opulus (Yaprak Döken Kartopu) /205 & Orta & Akdeniz Ülkeleri, Güney Avrupa \\
\hline 30 & Juniperus horizontalis (Yayılıcı Ardıç) /59 & $\mathrm{Az}$ & Kuzey Amerika \\
\hline \multirow[t]{2}{*}{31} & Tamarix tetranda (llgın)/33 & $\mathrm{Az}$ & Avrupa, Afrika, Batı Avrupa, Akdeniz, Doğu Asya \\
\hline & YER ÖRTÜCÜ TÜRLER /Adet & & \\
\hline 32 & Carpobrotus edulis (Kazayağı) /525 & $A z$ & Güney Afrika \\
\hline 33 & Aptenia cordifolia (Buz Çiçeği) /520 & $A z$ & Güney Afrika, Kuzey Amerika \\
\hline 34 & $\begin{array}{l}\text { Cerastium tomentosum (Serastiyum, Fareku- } \\
\text { lağı) } / 500\end{array}$ & $A z$ & Güney Avrupa, Doğu Avrupa \\
\hline 35 & Portulaca grandiflora (İpek Çiçeği) /520 & $\mathrm{Az}$ & Güneybatı Pelerin, Güney Afrika \\
\hline \multirow[t]{2}{*}{36} & Gazania rigens (Gazanya) /640 & $\mathrm{Az}$ & Güney Afrika \\
\hline & MEVSIMMLİK TÜRLER /Adet & & \\
\hline 37 & Tagetes erecta (Kadife Çiçeği) /610 & Orta & Meksika \\
\hline 38 & Calendula officialis (Portakal Nergisi) /430 & $\mathrm{Az}$ & Türkiye, Güney Avrupa \\
\hline
\end{tabular}


Araştırmadaki bitkisel tasarım projesinde yer alan bitki türleri genel olarak değerlendirildiğinde; çalışma alanının yoğun kullanıldığı sezonun yaz aylarına denk gelmesinden dolayı öncelikli olarak kurakçıl peyzaj ilkeleri doğrultusunda su isteği az ve sahil kuşağının bir özelliği olan yüksek tuz içeriğine dayanıklı türlerin seçiminin ön planda tutulmasına dikkat edilmiştir. Araştırma alanında kullanılan dolgu toprağının tuz içeriğinin düşük olmasına rağmen ilerleyen süreçte tuzun farklı şekillerde taşınmasına (rüzgâr, taban suyu seviyesinin yükselmesi ve deniz suyu baskını gibi) bağlı olarak değişime uğrama potansiyeli de göz önünde bulundurularak tuzluluk açısından dayanıklı bitkilerin tercih edilmesine de özen gösterilmiştir. Bitki seçimleri yapılırken estetik görüntülerin oluşturulması amacıyla görsel etkinliği yüksek olan türler tercih edilerek özellikle daha aktif kullanımın olduğu ilkbahar sonu ve yaz ayları boyunca çiçekli olan türlere daha fazla yer verilerek görsel canlılık ve işlevsellik kazandırılmıştır. Çalışma sahasındaki farklı rekreasyonel amaçlar için değerlendirilen (kamp yerleri, çocuk oyun alanları, piknik ve yeme-içme alanları gibi) bölgelerdeki bitkisel tasarım projesinde tercih edilen bitki türleri, çaış̧ma alanına uygun olarak değişkenlik göstermiştir. Peyzaj tasarımlarında bitkilerin görsel etkilerinden faydalanmanın yanı sıra hareket kontrolü, yönlendirme, sınırlama, görüş açısını değiştirme ve vurgulama işlevlerini yerine getirmek amacıyla da kullanımların olduğu araştırmalarda belirtmiştir (Evyapan ve Tokol, 2000; Yıldırım, 2000; Erbaş, 2003; Arın, 2010). Bu bağlamda, bitkisel tasarım projesinde tercih edilen tüm bitkiler, belirtilen işlevleri yerine getirmek adına kullanım amaçları doğrultusunda proje alanında yer alarak literatür ile uyum sergilemiştir.

Çalışma sahasındaki mevcut bitki türlerinin yaklaşık yarısının doğal türlerden olmasının yanı sıra bitkisel tasarım projesinde ilave olarak kullanılan bitkilerin yaklaşık \%34'ünün de doğal türlerden tercih edilmesi bölgeye adaptasyon ve su tasarrufuna katkı sağlanması açısından büyük avantaj sunmaktadır (Tablo 8). Ayrıca planlanan bitkisel tasarım projesinde, klasik peyzaj tasarımlarından farklı olarak görsel etkisi kuvvetli olan egzotik bitkilere su tüketiminin yüksekliği nedeniyle daha az yer verilmesi ve öncelikli bölgenin doğal bitki türleri ile su isteği az olan bitkilerin tercih edilmesi sonucu peyzaj tasarımının sürdürülebilirliğinin sağlanması da amaçlanmıştır. Yerel olmayan egzotik bitki türlerinin su isteğinin fazla olması, bakım maliyetlerinin yüksekliği ve adaptasyon sıkıntılarından kaynaklı olarak yaşam döngüsünün kısalığı nedeniyle kurakçıl peyzaj çalışmalarında kullanılmaması gerektiği yönündeki Çakar ve ark. (2018)'nın bildirişleri dikkate alındığında; araştırmamızda bu türlerin az miktarda tercih edilmesi ile literatür açısından benzerlik ortaya konulmuştur.

Kurakçıl peyzajda planlama ve tasarım aşaması kapsamında dikkate alınması gereken en önemli hususlardan biri; suyun etkin kullanıldığı peyzaj tasarımının işlevsel, estetik ve sürdürülebilir olmasının sağlanmasıdır (Yazgan ve Özyavuz, 2008; Çetinkale Demirkan ve Akat, 2017). Bu doğrultuda da kurakçıl peyzaj çalışmalarında tercih edilen bitkilerin; bölgenin ekolojik koşullarında kendine yetebilen, canlıı̆̆ını ve işlevselliğini koruyabilen türlerden seçilmesi gerekmektedir. Suyun etkin kullanımını benimseyen kurakçıl peyzaj yaklaşımında, yağmur suyu veya daha az sulamayla yaşamını devam ettiren bitki türlerinin tercih edilmesi ve bölgenin sahip olduğu ekolojik koşullara uygun doğal bitki türlerinin kullanımı; adaptasyon kolaylığı sağladığından sürdürülebilir olmasının yanı sıra ekonomik yararı da beraberinde getirmektedir (Atik ve Karagüzel, 2007; Barış, 2007; Gül ve ark., 2012; Çetinkale Demirkan ve Akat, 2017; Çakar ve ark., 2018). Bu bağlamda çalışma alanındaki mevcut bitkilerin dışında kullanılması planlanan bitki grupları incelendiğinde; ağaç grubuna ait \%50'lik bir orandaki türler ile 654 bitkinin yoğun miktarda alanda var olmasından dolayı ilave olarak bu gruptaki türlere çok fazla yer verilmemiştir. Fidan ve ark. (2008), peyzaj tasarımlarında sergiledikleri dendrolojik özelliklerinden dolayı göze en çok çarpan bitki grupları olarak ağaç türlerinin boylu ve geniş taç yapısına sahip olmasının, diğer bitkilere oranla daha yüksek su tüketimine neden olduğunu belirtmiştir. Bu doğrultuda hazırlanan bitkisel tasarım projesinde, tür sayısına göre dağılımlara bakıldığında; \%31,57'lik oranda ağaç grubundan türlerin az miktarda tercih edilerek bunun da yaklaşık yarıdan fazlasının bölgenin doğal bitki türlerinden olması literatür ile uyum göstermektedir (Tablo 8).

Tablo 8. Bitkisel tasarım projesinde kullanılan bitki gruplarına göre dağılımlar

\begin{tabular}{l|ccr}
\hline Bitki Grupları & $\begin{array}{c}\text { Bitki Türü Sayısı } \\
\text { (adet) }\end{array}$ & $\begin{array}{c}\text { Tür Sayısına Göre } \\
\text { Dağılım (\%) }\end{array}$ & $\begin{array}{c}\text { Bitki Sayısı } \\
\text { (adet) }\end{array}$ \\
\hline Ağaçlar & 12 & 31,57 & 109 \\
Ağaççıklar & 2 & 5,26 & 60 \\
Çalılar & 17 & 44,74 & 1690 \\
Yer Örtücüler & 5 & 13,17 & 2705 \\
Mevsimlikler & 2 & 5,26 & 1040 \\
\hline Toplam & $\mathbf{3 8}$ & $\mathbf{1 0 0 , 0 0}$ & $\mathbf{5 6 0 4}$ \\
\hline Doğal türler & $\mathbf{1 3}$ & $\mathbf{3 4 , 2 1}$ & $\mathbf{8 3 1}$ \\
\hline
\end{tabular}


Ağaçlar, ağaççıklar ve çalı grubu bitkiler birbirlerinden farklı yapı ve dokusal karakterler ortaya koyduklarından kullanım amaçları değişkenlik göstermektedir (Gültekin, 1994). Ağaççıklar, ağaçlara oranla daha küçük taç oluşturan, formu kolay kontrol edilebilen, bodur bir ağaç görüntüsü sergileyen, dar alanlarda vurgusu daha ön planda olan ve geniş alanlarda ise grup halinde kullanımları sonucu etkinliğini yüksek oranda arttıran bitki gruplarıdır (Akat ve ark., 2017). Çalışma sahasında $\% 4,17$ 'lik oran ile 1 ağaççık türü varken, ilave bir tür daha eklenmiştir (Tablo 8).

Ağaç ve çim türleri arasında geçiş sağlayan çalı grubu bitkiler; alttan çok sayıda sürgün veya dal oluşturabilen, kompakt gelişme gösteren ve peyzaj tasarımlarında çit, vurgu, perdeleme, yönlendirme ve topiary gibi çok amaçlı işlevleri olan türlerdir (Akat ve ark., 2017). Çaış̧ma sahasında \%29,16'ık bir oran ile 7 çalı türü bulunmaktayken, yeni türlerin eklenmesi sonucu bu rakam \%44,74'e çıkarıımıştır (Tablo 8).

Mevsimlik süs bitkileri; çoğunluğu tek yıllık, bazıları iki veya çok yıllık olan, peyzaj alanlarında değişik renk ve otsu yapıları ile mekânın görsel algısını arttıran, çiçekleriyle ortama canlılık veren ve yönlendirme işlevi gören bitki gruplarıdır (Yücel, 2002). Genel olarak peyzaj tasarımlarında ekolojik koşullara uygun olmayan bitki kullanımı ile çim ve mevsimlik süs bitkisi türlerine geniş boyutlarda yer verilmesi, azalmakta olan su kaynakları üzerinde olumsuz etkiler yaratmaktadır (Çetin ve Mansuroğlu, 2018). Bu doğrultuda çalışma alanında herhangi bir mevsimlik süs bitkisine rastlanılmazken, hazırlanan bitkisel tasarım projesinde; kullanıcıların yoğun zaman geçirdiği çocuk oyun parkları, piknik yerleri ile yeme-içme alanlarındaki yürüyüş yollarının kenarlarında; yönlendirme ve görsel etkiyi arttırma amacıyla su isteği düşük olan 2 mevsimlik süs bitkisi türüne $\% 5,26$ 'lık oran ile az miktarda yer verilerek literatür doğrultusunda hareket edilmiştir (Tablo 8).

Bölgenin ekolojik avantajları nedeniyle turizm sezonunun uzun sürmesi ve mevsimlik bitkilerin bakım işlemleri esnasında karşılaşılan güçlükler, bitkisel tasarım projesinde çok yıllık çiçekli yer örtücü bitkilerin tercih edilmesini gündeme getirmiştir. Bitkisel tasarım projelerinde ağaç, ağaççık ve çalı grupları yerleştirildikten sonra en kısa boylu bitkiler arasında sayılan yer örtücülerin kullanımı sonucu bitkisel ve mekânsal kompozisyon tamamlanmaktadır (Ouren, 1991). Mekân sınırlarının belirlenmesi, sert ve yumuşak zeminlerin ayrımının ortaya konulması ile alandaki çukur ve tümseklerin kaplanarak gizlenmesinde yer örtücü bitkiler; önemli bir rol oyna- maktadır (Booth, 1996). Ayrıca yer örtücü bitkilerin bulunduğu alanı kapatarak görsel etki yaratma özelliğinin yanı sıra toprak yüzeyinden suyun buharlaşması yoluyla meydana gelen kayıpları engelleyip su korunumuna katkı sağlaması ve birçok türünün sukkulent yapıda olması nedeniyle çim türlerine alternatif oluşturarak kurakçıl peyzaj çalışmalarında yüksek kullanım potansiyeline sahip olduğu da bildirilmektedir (Öztan ve Arslan, 1992; Bayramoğlu ve Demirel 2015; Akat ve ark., 2017; Çakar ve ark., 2018). Bu bağlamda kurakçıl peyzaj yaklaşımı doğrultusunda bitkisel tasarımın gerçekleştirileceği çaIışma sahasında yoğun su tüketimine sahip çim türlerine yer verilmeyerek \%13,17'lik bir pay ile ağırlıklı sukkulent yapıdaki 5 yerörtücü türünden faydalanılmasının, su tasarrufuna katkı sağlama açısından literatür doğrultusunda hareket edildiğini ortaya koymaktadır (Tablo 8).

Barış (2007), peyzaj tasarımlarında rahatlatıcı etkiye sahip, fonksiyonel, estetik ve tamamlayıcı öğelerden çim türlerine yüksek su tüketimleri, bakım işlemlerinin yoğun ve zahmetli olmasından dolayı kurakçıl peyzaj çalışmalarında yer verilmemesinin önemli bir husus olduğunu vurgulamıştır. Bununla birlikte kurakçıl peyzaj tasarımları ile ilgili yapılan birçok araştırmada çok tercih edilmemekle birlikte, estetik görüntünün sağlanması ve işlevselliğin arttırılması amacı ile su isteği az olan ve kuraklığa dayanıklı çim türlerinin, göz önünde yer alan ve insan sirkülasyonunun fazla olduğu yerlerde sınırlı kullanımlarına baş vurulduğu da belirtilmiştir (Barış, 2007; Yazgan ve Özyavuz, 2008; Çorbacı 2011a). Araştırmada kurakçıl peyzaj ilkeleri doğrultusunda yapılması planlanan bitkisel tasarım projesinde, çoğu çim türünün su ve bakım isteklerinin fazla olması ile çalışma alanının günübirlik ve kamp yeri olarak değerlendirilmesi sonucu yoğun insan hareketliliğine bağlı zarar görebilme potansiyeli de düşünülerek çim kullanımı tercih edilmemiştir. Bu durum literatür ile kısmen benzerlik ortaya koyarken, bölgenin ekolojik koşulları ve çalışma alanının plaj olarak kullanımı nedeniyle alandaki su tüketimi ve bakım işlemlerinin daha da azaltılması amacıyla yoğunluklu olarak sukkulent yapıdaki yer örtücü türlere yer verilmiş olması ile de farklılık ortaya koymuştur.

Hazırlanan bitkisel tasarım projesinde kullanılan bitki grupları su ihtiyacı açısından tür bazında irdelendiğinde; oransal olarak \%68,42'lik kısım ile 26 türün su isteği az ve \%31,57'lik oran ile 12 türün su isteği orta düzeyde olan türlerin seçildiği görülmektedir (Tablo 9). Ayrıca kurakçıl peyzaj ilkeleri doğrultusunda hazırlanan bitkisel tasarım projesinde su tüketimi yüksek bitki türlerine yer verilmemesi de su tasarrufuna katkı sağlama bakımından literatür ile örtüşmektedir. 
Kurakçıl Peyzaj Çalışmalarında Bitkisel Uygulamalar: Muğla-Sarıgerme Halk Plajı Örneği

Tablo 9. Bitkisel tasarım projesinde kullanılan bitki türlerinin su isteklerine göre gruplandırılması

\begin{tabular}{l|rrr|r}
\hline Bitki Grupları & \multicolumn{1}{c}{$\begin{array}{l}\text { Su isteği yük- } \\
\text { sek (adet) }\end{array}$} & $\begin{array}{c}\text { Su isteği } \\
\text { orta (adet) }\end{array}$ & $\begin{array}{c}\text { Su isteği } \\
\text { az (adet) }\end{array}$ & $\begin{array}{r}\text { Bitki Tür Sayısı } \\
\text { (adet) }\end{array}$ \\
\hline Ağaçlar & 0 & 6 & 6 & 12 \\
Ağaççıklar & 0 & 0 & 2 & 2 \\
Çalılar & 0 & 5 & 12 & 17 \\
Yer Örtücüler & 0 & 0 & 5 & 5 \\
Mevsimlikler & 0 & 1 & 1 & 2 \\
\hline Toplam & 0 & $\mathbf{1 2}$ & $\mathbf{2 6}$ & $\mathbf{3 8}$ \\
\hline
\end{tabular}

Araştırmadaki bitkisel tasarım projesinde tercih edilen bitki gruplarının kendi içindeki su intiyaçlarına göre dağıIımları irdelendiğinde; 12 ağaç ve 2 mevsimlik süs bitkisi türüne sahip bitki gruplarının \%50'si, 17 çalı türünün $\% 70,58$ 'i, 2 ağaççık ve 5 yer örtücü türünün ise tamamının su isteğinin az ve ağaç ile mevsimlik süs bitkisi gruplarının \%50'si ve çalı grubu bitkilerin \%29,41'inin su isteğinin ise orta düzeyde olduğu dikkat çekmektedir (Şekil $5)$.

Kurakçıl peyzaj düzenleme çalışmalarının başarısındaki en önemli ölçütlerden sayılan su temini ile tercih edilen bitkiler su isteklerine göre gruplandırılarak projede yer verilmesi ve su ihtiyacı düşük türlerin kullanımının ön planda tutulması büyük önem taşımaktadır. Araştırma kapsamında su istekleri benzer türler birbirine yakın alanlarda değerlendirilerek su tüketim düzeylerine göre gruplandırılıp bitkisel tasarımın su zonlarına göre gerçekleştirilmesi, su tasarrufuna katkı sağladığı gibi kurakçıl peyzaj çalışmasının etkinliğini daha fazla arttırmaktadır. Çorbacı ve ark. (2011a), kurakçıl peyzaj çalışmalarında su kullanım zonlarının ayrı bölgelerde tek bir parça halinde oluşturulmasının, sulamanın etkinliği ve bakım işlemlerinin pratik bir şekilde çözülebilmesi açısından önemli olduğunu belirtmiştir. Literatürdeki bu bildiriş doğrultusunda, hazırlanan bitkisel tasarım projesinde yüksek su ihtiyacına sahip bitkilere yer verilmeyerek, su ihtiyacı orta türlerin $\% 31,57$ 'lik ve az olan türlerin ise $\% 68,42$ 'lik oranda kullanımı kurakçıl peyzaj yaklaşımını destekleyen bir tutum olarak karşımıza çıkmaktadır.

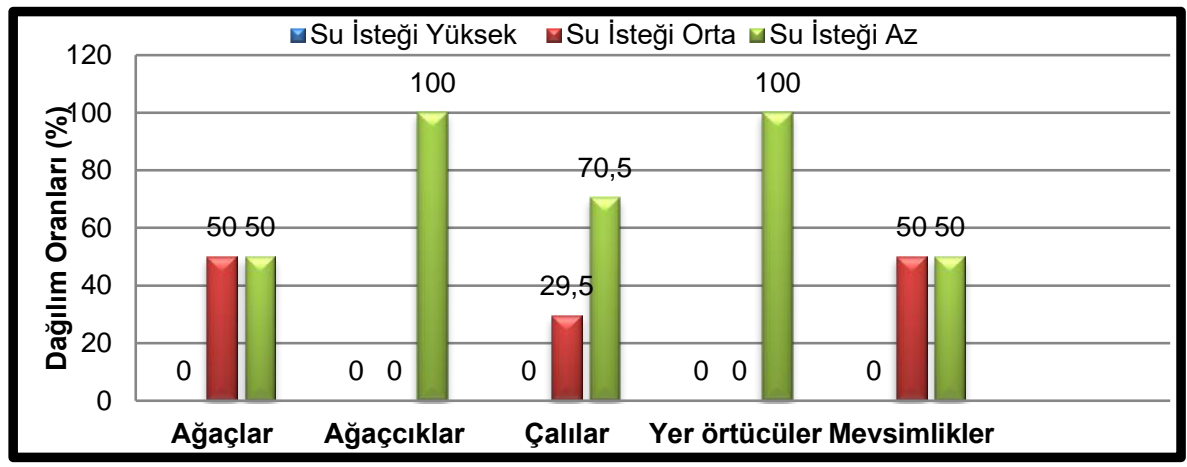

Şekil 5. Bitkisel tasarım projesinde kullanılan bitki gruplarının su isteklerine göre dağılımları

Ayrıca çalışma sahasındaki mevcut 24 türün sadece 2 'sinin su isteğinin yüksek olması ve bu türlere ait bitkilerin daha çok bina oturum alanlarına yakın noktalarda bulunduğu gözlemlenmiştir. Bununla birlikte hazırlanan bitkisel tasarım projesinde; özellikle restoran, büfe ve alışveriş binalarının bulunduğu kısımlar ile giriş-çıkış noktaları gibi hareketliliğin yoğun olduğu yerlerde orta su isteğine sahip bitkilerin gruplar halinde kullanımına sınırlı miktarda yer verilirken, su kaynaklarına en uzak noktalardaki bölgelerde ise su intiyacı düşük olan kurağa dayanıklı bitki türlerinin kullanımı tercih edilmiştir (Şekil $6)$. 


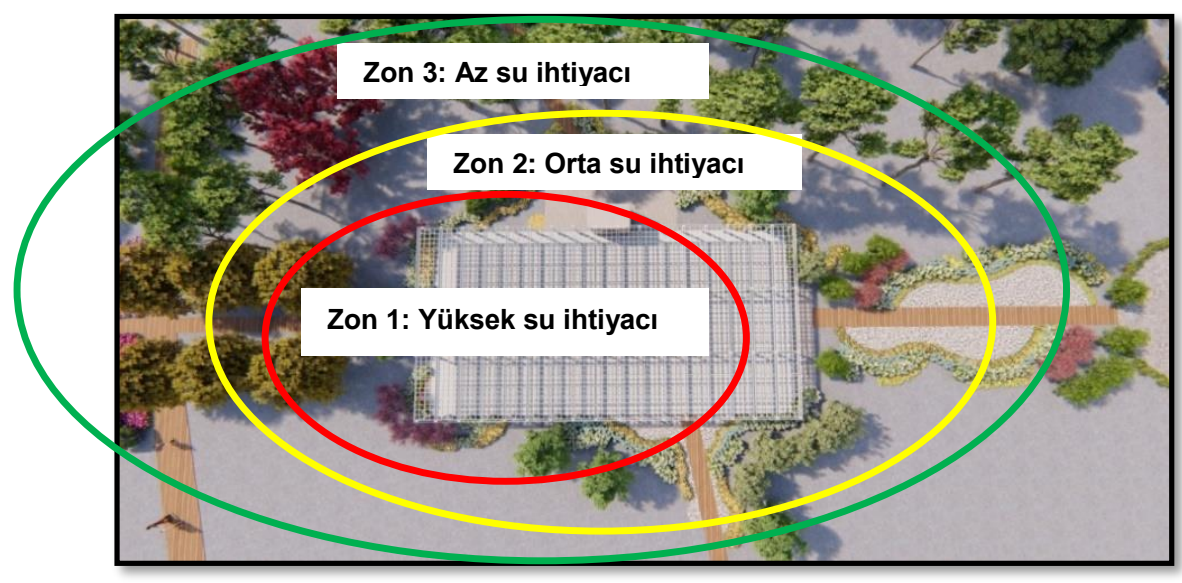

Şekil 6. Bitkisel tasarım projesinde su kullanım zonları

Kurakçıl peyzaj yaklaşımında, akıllı ve stratejik sulama en önemli konuların başında yer almaktadır. Birçok araştırmada suyun etkin kullanılabilmesi adına su tüketimini en aza indiren, alanın büyüklüğü ve kullanım amacına göre en uygun sulama sisteminin seçilmesi gerektiğini bildirilmiştir (Barış, 2007; Yazgan ve Özyavuz, 2008). Bu amaçla kurakçıl peyzaj tasarımlarında öncelikle kullanılacak bitkilerin, su tüketim miktarlarının bilinmesi ve ardından da türün intiyaç duyduğu suyun, yağışlarla karşılanamayan kısmının giderilmesinde su tasarrufu sağlayan uygun bir sulama sisteminin tercih edilmesi gerekmektedir. Çorbacı ve ark. (2011b), modern sulama sistemlerinin otomatik bir yapıya sahip olmasının sulamaya ayrılan zaman ve iş̧̧ilik masraflarını azaltarak su tasarrufuna katkı yaratmasından dolayı avantajlı bir uygulama olarak karşımıza çıktığını belirtmiştir. Mevcut çaış̧ma alanındaki bitkilerin yağışlara ilaveten elle sulama işlemleri gerçekleştirilirken, kurakçı peyzaj yaklaşımı doğrultusunda gerçekleştirilmesi planlanan peyzaj tasarımında su ve iş gücü tasarrufuna katkı sağlama açısından literatür ile uyumlu hareket etmek adına damlama sulama sisteminin kullanımı önerilmiştir.

Kurakçıl peyzaj tasarımlarında, toprak yüzeyinden buharlaşmayı en aza indirmek ve su tutma kapasitesini arttırmak amacıyla organik ve inorganik malç materyallerinin kullanımına başvurulmaktadır. Ağaç kabukları, odun talaşı, çam ibreleri, meyvelerin sert kabukları, ince kıyılmış budama artıkları, yaprak ve saman gibi organik yapıda olan malç materyallerinin ayrışma sonucu toprak özelliklerinin iyileştirilmesin de daha olumlu etkisinin olduğu belirtilmiştir (Çorbacı ve ark., 2011a; Çorbacı ve ark., 2011b). Bu doğrultuda peyzaj tasarım alanında özellikle binalara yakın noktalarda sahada mevcut su isteği yüksek ve orta düzeydeki bitkilerin su tüketiminin yoğun olması nedeniyle alt kısımlarında, organik yapısından dolayı daha çok ağaç kabuğu ile inorganik malçlar- dan cüruf kullanımına yer verilerek kurakçıl peyzaj kapsamında sudan tasarrufa katkı sağlanıp literatür ile benzer uygulamaların tercih edildiği görülmektedir. Ayrıca malç uygulamasının dışında toprak yüzeyinden buharlaşmayla su kaybı önlemesi ve su tüketimini azaltması amacıyla karşımıza çıkan bir diğer uygulama şekli olan taş bahçelerinin kullanımı estetik ve çevreci bir yaklaşım olarak dikkat çekmektedir. Çakar ve ark. (2018), kurakçıl peyzaj çalışmaları kapsamında estetik amaçlı az miktarda da olsa yer verilen çim alanlara, yer örtücü bitkiler ile malç kullanımı gibi çözümler dışında kumtaşı, çakıl taşı, mermer, granit, andezit, bazalt, kalker, dolomit, kayrak taşı ve traverten gibi birçok doğal malzemeden faydalanılarak taş bahçesi oluşturulmasının alternatif yarattığını belirtmiştir. Araştırmada bu amaçlar doğrultusunda dolomit taşının kullanımına da yer verilmesi literatür ile paralel hareket edildiğinin bir kanıtıdır.

Araştırma kapsamında kurakçıl peyzaj ilkeleri doğrultusunda bitkisel tasarım projesinin tamamlanmasının ardından alanların kullanım amaçları ve dağılımları incelendiğinde; başlangıçtaki ilk kullanım durumlarına oranla yeşil ve ormanlık alanlarda \%5'lik, kaldırımlarda \%0,6'ık ve araç yollarında $\% 0,3^{\prime}$ lük artışların olduğu belirlenmiştir. Çalışma alanındaki mevcut binalar kaldırılarak farklı amaçlar doğrultusunda kullanılacak yeni binaların ilave edilmesi ile bina oturum alanlarında \%1,7'lik bir artışın meydana geldiği tespit edilmiştir. Plajın yaz aylarındaki kullanım yoğunluğuna bağlı olarak yaşanan sıkıntılara çözüm oluşturabilmek adına otopark alanında 300 araçlık bir ilavenin yapılması ile \%2,8'lik bir artışın meydana geldiği saptanmıştır. Ayrıca kumsal alanlardan denize ulaşabilmek amacıyla yürüyüş yollarının tasarlanması ve spor alanının oluşturulması nedeniyle bu alanlarda \%2,2'lik bir azalmanın meydana geldiği de görülmektedir (Tablo 10). 
Tablo 10. Bitkisel tasarım projesindeki alanların kullanım amaçları ve dağılımları

\begin{tabular}{l|rr}
\hline Kullanım Amaçları & Alan $\left.\mathbf{( m}^{\mathbf{2}}\right)$ & Dağılım Oranları (\%) \\
\hline Yeşil ve Ormanlık Alanlar & 39325,18 & 44,32 \\
Kaldırımlar & 1017,02 & 1,14 \\
Araç Yolları & 2033,23 & 2,29 \\
Bina Oturum Alanları & 1748,64 & 1,97 \\
Yürüyüş Yolu & 4367,43 & 4,92 \\
Kumsal Alanlar & 32092,48 & 36,17 \\
Otopark Alanları & 5115,20 & 5,76 \\
Spor Alanı & 3024,09 & 3,40 \\
\hline Toplam Çalışma Alanı & $\mathbf{8 8 7 2 3 , 2 7}$ & $\mathbf{1 0 0 , 0 0}$ \\
\hline
\end{tabular}

Sonuç olarak çalışmanın yürütüldüğü alanın çevresinde turizm tesislerinin yoğun bulunması nedeniyle turistlerin yanı sıra yöre halkının da ekonomik bir şekilde günübirlik olarak yararlanabileceği "Muğla-Sarıgerme Halk Plajı"nın ziyaretçilerin kullanımına sunabilmek adına kurakçıl peyzaj ilkeleri doğrultusunda görsel, estetik ve sosyal alanların oluşturulması amacı ile hazırlanan bitkisel tasarım projesinde doğal bitki türlerinin seçilmesine dikkat edilerek su kaynaklarının korunumu, sürdürülebilirliği ile tasarrufuna katkı sağlama bakımından bölgede öncülük edilmiştir. Bu doğrultuda önerilen bitkisel tasarım projesinin, çevrenin korunmasının yanı sıra bölgeye ekonomik, sosyal ve kültürel açıdan da katkı sağlayacağı da düşünülmektedir.

\section{SONUÇLAR}

Günümüzde küresel ısınmaya bağlı olarak yaşanan kuraklığın etkisiyle azalmakta olan su kaynaklarının korunması ve her alanda etkin kullanımının sağlanması büyük önem taşımaktadır. Bu doğrultuda peyzaj tasarımlarında, bölgenin ekolojik koşullarına uygun daha çok doğal bitki türlerinin yer aldığı ve görsel kalitenin de göz ardı edilmeyerek sürdürülebilirliğin sağlandığı kurakçıl peyzaj yaklaşımının ön planda tutulmasının çevrenin korunmasının yanı sıra su kaynaklarının etkin kullanımına da olanak tanıdığı bilinmektedir. Araştırmanın yürütüldüğü sahil bandında yer alan "Muğla-Sarıgerme Halk Plajı"nın özellikle mevsimsel kuraklıkların etkisi altında kalması su etkin peyzaj tasarımları arasında yer alan kurakçıl peyzaj yaklaşımından yararlanmayı zorunlu kılmıştır.

Bu bağlamda araştırmada kurakçıl peyzaj planlama ve tasarım aşaması kapsamında öncelikli çalışma alanın fiziki durumu tespit edilerek 24 tür ile 790 bitkinin yer aldığı ve sahadaki mevcut türlerin kurakçıl peyzaja uygun olan bazılarının tekrar tercih edilmesi sonucu bitkisel tasarım projesinde 38 tür ile 5604 bitki kullanılarak, toplamda 6394 bitkinin bulunduğu görülmektedir. Bununla birlikte mevcut alandaki bitkilerin yarıdan fazlasının do- ğal tür olmasına ilaveten bitkisel tasarım projesinde önerilenler ile toplam 54 türün 17'sinin bölgenin doğal bitki türlerinden olduğu tespit edilmiştir. Çalışma sahasındaki mevcut türlerin \%8,33'ünün su isteğinin yüksek, geriye kalan kısmın su isteğinin yarı yarıya az ve orta düzeyde olduğu belirlenirken, bitkisel tasarım projesinde kullanılan türlerin $\% 68,42^{\prime}$ lik az ve $\% 31,57^{\prime}$ lik oranla orta su isteğine sahip bitkilerden seçilmiş olmasının, kurakçıl peyzaj yaklaşımında su tasarrufu açısından doğru bir uygulama olduğunu gözler önüne sermektedir.

Ayrıca çalışma alanındaki mevcut bitkilerin çoğunun doğal bitkilerden oluşmasının yanı sıra bitkisel tasarım projesinde önerilen türlerin yarıdan fazlasının az su isteğine sahip olması ile su zonlarının kullanımı doğrultusunda orta su isteği olan türlere düşük oranda yer verildiği görülmektedir. Bunlara ilaveten bitkisel tasarım projesinde özellikle su tüketimi yüksek olan çim türleri kullanılmayarak örtü materyali olarak malç uygulamalarının tercih edilmesi ve projedeki bitki varlığının yarıdan fazlasını oluşturan yer örtücülerin yaklaşık $\% 57,85$ 'inin sukkulent yapı sergilemesi, toprak yüzeyinden buharlaşmanın engellenmesi ile su tasarrufuna katkı sağlarken çevrenin korunması açısından da oldukça önem taşımaktadır.

Araştırmada Ortaca İlçesi'ndeki "Muğla-Sarıgerme Halk Plajı" için kurakçıl peyzaj ilkeleri doğrultusunda hazırlanan bitkisel tasarım projesinin, bölgedeki diğer yerel yönetimler ve turistik tesislerin su etkin peyzaj düzenlemeleri kapsamında yapmayı planladığı çalışmalarda tercih edebileceği bitki türlerine alternatifler sunması ve örnek oluşturmasının yanı sıra sürdürülebilir peyzaj tasarımlarının gerçekleştirilmesine katkılar sağlaması sonucu çevrenin korunmasına yönelik öncülük edilebileceği kanaatine varılmıştır.

\section{TEŞEKKÜR}

Bu çalışma, Dr. Öğr. Üyesi Hülya AKAT'ın danışmanlığında, Serap ÇÖP tarafından hazırlanan 'Sürdürülebilir Peyzaj Uygulamalarına Yönelik Bitkilendirme ÇalışmaIarının Kurakçıl Peyzaj Yaklaşımına Göre İrdelenmesi: 
"Sarıgerme Günübirlik Halk Plajı Örneği”' yüksek lisans tezinin verileri kullanılarak hazırlanmıştır.

\section{KAYNAKLAR}

Acar, C., Demirbaş, E., Dinçer, P., Acar, H. (2003). Anlamsal Farklılaşım tekniğinin bitki kompozisyonu örneklerinde değerlendirilmesi, S.D.Ü. Orman Fakültesi Dergisi Seri: A, 1: 15-28.

Akan, H., Öz, A., Pekmez, H. (2018). Ortaca (Muğla) yöresinde halk arasında kullanılan bazı bitkiler, Türk Tarım Gıda Bilim ve Teknoloji Dergisi, 6(9):1168-1174.

Akat, H., Çöp, S. (2018). Muğla Sıtkı Koçman Üniversitesi Yerleşkesinin yeşil alanlarının "Xeriscape" yaklaşımı (Kurakçıl peyzaj) açısından değerlendirilmesi, International Congress on Agriculture and Forestry Research, 8-10 April 2018, Marmaris, Turkey, 78-97.

Akat, H., Şahin, O., Demirkan, G.Ç. ve Saraçoğlu, A.Ö. (2017). Süs Bitkileri Üretim Teknikleri, Efil Yayınevi Yayınları, 144 s.

Aklanoğlu, F. (2007). İklim değişikliğinin peyzaj tasarımı ve uygulamaları üzerine etkisi, Uluslararası İklim Değişikliği ve Çevresel Etkileri Konferansı (UKIDEK), 18-20 Ekim 2007, Konya.

Aküzüm, T. ve Çakmak, B. (2008). Gıda güvenliği açısından su yönetiminin değerlendirilmesi. Standart Ekonomik ve Teknik Dergi, Y/47, N/549, TSE Dergisi, 55-63.

Anonim, (2019). Sarıgerme. T.C. Turizm ve Kültür Bakanlığı, https://www.mugla.ktb.gov.tr/sarigerme.html. (Erişim Tarihi: 18.06.2019).

Appenzerler, T., Dimick, R.D. (2004). "Dünya Alarm Veriyor”, National Geography, www.akuastrateji.sumae.gov.tr/downloads/temel_tr/Internet_Derlem.pdf (Erişim Tarihi: 20.07.2019)

Arın, Ö. (2010). Bitkisel Tasarımın Görsel Açıdan Değerlendirilmesine Yönelik Bir Araştırma: Bursa Soğanlı Botanik Parkı Örneği, Yüksek lisans tezi, ITÜ Fen Bilimleri Enstitüsü.

Atalık, A. (2006). Küresel ısınmanın su kaynakları ve tarım üzerine etkileri. Bilim ve Ütopya Dergisi, 139: 18-21.

Atik, M., Karagüzel, O. (2007). Peyzaj Mimarlığı Uygulamalarında Su Tasarrufu Olanakları ve Süs Bitkisi Olarak Doğal Türlerin Kullanım Önceliği. Tarımın Sesi TMMOB Ziraat Mühendisleri Odası Antalya Şubesi Yayını, 15: 9-12.

Barış, M.E. (2007). Sarıya Bezenen Kentlerimizi Kimler ve Nasıl Yeniden Yeşertebilir, http://www.peyzajmimoda.org.tr/genel/bizden_de-

tay.php?kod=1173\&tipi $=2 \&$ sube $=0$ (Erişim Tarihi: 30 Ocak 2019).

Baykan, N.M., Birişçi, T. (2013). Ege Üniversitesi Ziraat Fakültesi bahçesi örneğinde sürdürülebilir peyzaj tasarımı yaklaşımıyla Xeriscape, V. Süs Bitkileri Kongresi, 06-09 Mayıs 2013, Yalova, 2: 523-529.

Bayramoğlu, E. (2013). Damla Sulama Sistemi ile Berberis thunbergii 'Atropurpurea nana' ve 'llex aquifolium' Bitkilerinin Sulanma Olanağının Araştırılması, Doktora tezi, Karadeniz Teknik Üniversitesi.
Bayramoğlu, E. (2016). Sürdürülebilir peyzaj düzenleme yaklaşımı: KTÜ Kanuni Kampüsünün Xeriscape açısından değerlendirilmesi. Artvin Çoruh Üniversitesi Orman Fakültesi Dergisi, 17(2): 119-127.

Bayramoğlu, E., Demirel, Ö. (2015). Xerophytic Landscape. In: Environment and Ecology at the Beginning of $21^{\text {st }}$ Century, ST. Kliment Ohridski University Press, Sofia, 180-190.

Bayramoğlu, E., Ertek, A., Demirel, Ö. (2013). Su tasarrufu amacıyla peyzaj mimarlığı uygulamalarında kısıntılı sulama yaklaşımı. Inönü Üniversitesi Sanat ve Tasarım Dergisi, 3(7):45-53.

Booth, N.K. (1996). Basic Elements of Landscape Architectural Design. Waveland Press, Inc. Illinois.

Bozoğlu, B. Keskin, B. ve Çavdar S. (2003). Küresel Isınma, 6. Çevre Sorunları Öğrenci Yaklaşımları Sempozyum, Nisan 2003, Mersin.

Çakar, H., Akat Saraçoğlu, Ö., Akat, H. (2018). Xeriscape YakIaşımı ile Kurak Ortamda Sürdürülebilir Peyzaj: Ege Üniversitesi Bayındır MYO Bahçesi örneği, ISUEP2018 Uluslararası Kentleşme ve Çevre Sorunları Sempozyumu: Değişim/Dönüşüm/Özgünlük, 28-30 Haziran 2018, Eskişehir, 1:214-221.

Çakmak, B., Gökalp, Z. (2011). İklim değişikliği ve etkin su kullanımı, Tarım Bilimleri Araştırma Dergisi, 4(1):87-95.

Çetin, N., Mansuroğlu, S. (2018). Akdeniz koşullarında kurakçıl peyzaj düzenlemelerinde kullanılabilecek bitki türlerinin belirlenmesi: Antalya/Konyaaltı örneği. Ege Üniversitesi Ziraat Fakültesi Dergisi, 55(1):11-18.

Çetinkale-Demirkan, G., Akat, H. (2017). Kurak bölgelerde su etkin peyzaj düzenlemeleri yaklaşımıyla 'Xeriscape'. 3. ASM Uluslararası Tarım ve Çevre Kongresi Bildiriler Kitabı, 16-18 Kasım, Antalya, 9-18.

Çorbacı, Ö. L., Ertekin, M., Özyavuz, M. (2011a). Kurak ve yarı kurak alanlarda peyzaj mimarlığı uygulamaları, Kurak ve Yarı Kurak Alan Yönetimi Çalıştayı, 5-8 Aralık 2011, Nevşehir.

Çorbacı, Ö. L., Özyavuz, M., Yazgan, M. E., (2011b). Peyzaj mimarlığında suyun akıllı kullanımı: Xeriscape water-wise in landscape architacture: Xeriscape. Tarım Bilimleri Araştırma Dergisi, 4 (1):25-31.

Dönmez, Ş., Çakır, M., Kef, Ş. (2016). Bartın'da yetişen bazı tıbbi ve aromatik bitkilerin peyzaj mimarlığında kullanımı. Süleyman Demirel Üniversitesi Mimarlık Bilimleri ve Uygulamaları Dergisi, 1(2):1-8.

Elevitch, C., Wilkinson, K. (2014). "Greater Plant and Soil Health for Less Work" Agroforestry.net, http://www.agroforestry.net/pubs/Sheet_Mulching.html, (Erişim Tarihi: 05 Ocak 2019).

Erbaş, E. (2003). Peyzaj Düzenlemelerinde Bitkisel Tasarım 'Bahçeşehir Doğa Parkı Örneği'. Yüksek Lisans Tezi, İ.T.Ü. Fen Bilimleri Enstitüsü, İstanbul.

Ersoy, Ş. (2006). Küremiz ısınıyor. Bilim ve Ütopya Dergisi, 139: 5-13.

Ertop, G. (2009). Küresel Isınma ve Kurakçıl Peyzaj Planlaması. Ankara Üniversitesi Fen Bilimleri Enstitüsü, Yüksek Lisans Tezi, 134, Ankara.

Eşbah, H. (2010). Kurakçıl Peyzaj, PMO İstanbul Şubesi Semineri.

Evyapan, G. A., Tokol, A. S. (2000). Peyzaj Tasarımı Ders Notları, Orta Doğu Teknik Üniversitesi Yayınları, Ankara. 
Fidan, C., Duran, C., Kırış, R. (2008). TMMOB 2. su politikaları, Kongre Sempozyum Bildiriler Kitabı, 39-47. http://www.imo.org.tr/ekutuphane/index.php?yayinkod $=577 \&$ belgeadi=TMMOB\%202.\%20Su\%20Politikalar\%FD\%20Kongresi\%20-\%201.\%20Cilt (Erişim Tarihi: 22.12.2019).

Gül, A., Özçelik, H., Uzun, Ö.F. (2012). Isparta yöresindeki bazı doğal yer örtücü bitkilerin adaptasyonu ve özellikleri, Süleyman Demirel Üniversitesi Fen Bilimleri Enstitüsü Dergisi, 16(2):133-145.

Gültekin, E. (1994). Bitki Kompozisyonu. Ç.Ü. Ziraat Fakültesi Ders Kitabı, No: 10. Adana.

Güvenç, İ., Demiroğlu, D. (2016). Kilis 7 Aralık Üniversitesi Merkez Yerleşkesi yeşil alanlarının "Xeriscape" (Kurakçıl peyzaj düzenlemesi) açısından değerlendirilmesi, ISEM2016, $3^{\text {rd }}$ International Symposium on Environment and Morality. 4-6 Kasım 2016, Alanya, 389-400.

Kapluhan, E. (2013). Türkiye'de kuraklık ve kuraklığın tarıma etkisi. Marmara Coğrafya Dergisi, (27): 487-510.

Karaman, S., Gökalp, Z. (2010). Küresel ısınma ve iklim değişikliğinin su kaynakları üzerine etkileri, Tarım Bilimleri Araştırma Dergisi, 3(1): 59-66.

Kazan, D. (2007). Ortaca (Muğla) İlçesinin Etnobotaniği. Muğla Üniversitesi, Fen Bilimleri Enstitüsü, Biyoloji Anabilim Dalı, Yüksek Lisans Tezi, Muğla.

Koçer, F., Kurt, L., İmalı, A., Karahan, F. (2009). Küresel ısınmanın ekolojik etkileri, 1. Ulusal Kuraklık ve Çölleşme Sempozyumu Bildiriler Kitabı, 16-18 Haziran 2009, Konya, 205213.

Metin, M.Z., Koçan, N. (2020). Ankara Etimesgut Yıldırım Beyazıt Parkı Örneğinde kurakçıl peyzaj tasarım uygulaması. Mehmet Akif Ersoy Üniversitesi Fen Bilimleri Enstitüsü Dergisi, 11(Ek 1): 313-323.

Ouren, S. (1991). Planning Settlements Naturally, Packard Publishing Limited, Chicester, UK.
Öztan, Y., Arslan, M. (1992). İç Anadolu Bölgesi Ekolojik Koşullarına Uygun Sukkulent (Etli Yapraklı) Bitki Türlerinden Peyzaj Mimarlığı Çalışmalarında Yer Örtücü Olarak Yararlanma Olanakları, Tissamat Basımevi, Ankara.

Öztürk, K. (2002). Küresel iklim değişikliği ve Türkiye'ye olası etkileri. Gazi Üniversitesi Eğitim Fakültesi Dergisi, 22(1): 47-65.

Taner, T.M. (2010). Peyzaj Düzenlemesinde Suyun Etkin Kullanımı: Kurakçıl Peyzaj. Yüksek Lisans Tezi, Ege Üniversitesi Fen Bilimleri Enstitüsü, İzmir.

Tülek, B. (2008). "Xeriscape” Kurakçıl Peyzaj. Anakara Üniversitesi Fen Bilimleri Enstitüsü Yüksek Lisans Semineri, Ankara Ulusoy Tohumculuk, http://www.ulusoyseed.com.tr/urunler/cim-tohumucesitleri/festuca-rubracommutata, (Erişim Tarihi: 17.12.2019).

Tülek, B., Barış, M.E. (2011). Orta Anadolu iklim koşullarında su etkin peyzaj düzenlemelerinin değerlendirilmesi, Mustafa Kemal Üniversitesi Ziraat Fakültesi Dergisi, 16(2): 113.

Weinstein, G. (1999). Xeriscape Handbook: A How-to Guide to Natural, Resource-wise Gardening, ISBN 1-55591-346-6, Fulcrum Publishing, Colorado.

Yazgan, M.E., Özyavuz, M. (2008). Xeriscape (Kuru Peyzaj) Peyzaj Mimarlığında Yeni Bir Sistem, Yayınlanmamış Ders Notları, Ankara.

Yazıcı, N., Dönmez, Ş., Şahin, C. (2014). Isparta kenti peyzaj düzenlemelerinde kullanılan bazı bitkilerin kurakçıl peyzaj tasarımı açısından değerlendirilmesi. Kastamonu Üniversitesi Orman Fakültesi Dergisi, 14(2): 199-208.

Yıldırım, B.T. (2000). Bitki Materyali I. Basılmamış Ders Notları. Ege Üniversitesi Ziraat Fakültesi Peyzaj Mimarlığı Bölümü, İzmir.

Yücel, E. (2002). Türkiye 'de Yetişen Çiçekler ve Yer Örtücüler. Etam Yayınevi, ISBN 975-93746-1-7, Eskişehir. 